\title{
Social vulnerability and its possible relation to the principal causes of morbidity and mortality in the Mexican state of Oaxaca
}

\author{
Ana María González-Villoria* (i) and Roberto Ariel Abeldaño Zuñiga
}

\begin{abstract}
The health status of a population is the conjunction of many biological, political and social factors. The biological representations of diseases are attributed to factors, such as ischemic heart disease, that are attributed to unhealthy lifestyles when individuals have high levels of cholesterol and triglycerides, or lack of physical activity, or to genetic factors while ignoring social factors such as poverty. This study observes how morbidity and mortality of the population could be affected by living conditions.
\end{abstract}

Keywords: Environmental health risk, Indoor air pollution, Unsafe water

\section{Introduction}

Vulnerability is defined as the susceptibility to be harmed, or as the degree to which a system is susceptible and cannot withstand adverse effects [1]. It is marked by different factors: biological, cultural, social, economic, political, geographic, as well as diseases, educational level, age, gender, social status, behaviour and housing, which make certain groups more sensitive to premature and excessive morbidity and mortality. Moreover, these factors are not mutually exclusive [2]. Consequently, the same groups can present these vulnerabilities or disadvantage factors in a cumulative way; hence, those groups that tend to accumulate a greater number of factors are more likely to suffer injury or have a specific priority need in comparison to the rest of the population [2].

The state of Oaxaca, like every state within the Mexican Republic, has access to priority health programs; however, it ranks among the last places in health indicators in the national health surveys. Why does this state present such disparity? A possible answer could be found by analysing different social and economic factors related to vulnerability in order to clarify the main issues that may affect this phenomenon, so that the major health needs of the people of Oaxaca would be considered.

\footnotetext{
* Correspondence: gonzalezvilloria@yahoo.com.mx

Guillermo Rojas Mijangos S/N, Miahuatlán de Porfirio Díaz, Universidad de la Sierra Sur, Oaxaca, Mexico
}

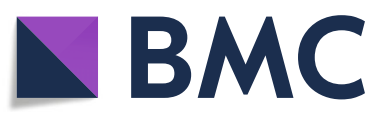

(c) The Author(s). 2018 Open Access This article is distributed under the terms of the Creative Commons Attribution 4.0 International License (http://creativecommons.org/licenses/by/4.0/), which permits unrestricted use, distribution, and reproduction in any medium, provided you give appropriate credit to the original author(s) and the source, provide a link to the Creative Commons license, and indicate if changes were made. The Creative Commons Public Domain Dedication waiver (http://creativecommons.org/publicdomain/zero/1.0/) applies to the data made available in this article, unless otherwise stated.

\section{Methodology}

To carry out the social study of living conditions we analysed reports of the National Institute of Statistics and Geography (INEGI) [3], Ministry of Health (SESA) [4] and the National Survey of Health and Nutrition (ENSANUT 2012) [5], as well as citizen reports of access to health care in Oaxaca. Once the social data were obtained, health conditions were compared between the states ranked from 1 to 32, with the lowest and highest degrees of social vulnerability [6] The ranking of the principal factors associated with diabetes and hypertension, living conditions and principal causes of mortality were obtained by dividing the rank occupied by the state by the total number of states (32) Mexico has 32 states, so the highest value implies the worst conditions. World Health Organization (WHO) [7] reports and published scientific articles were consulted for biological studies associated with social conditions. Finally, the work data was analysed for morbidity and mortality related to living conditions in Oaxaca.

\section{Health status of the Oaxaca population}

The state of Oaxaca is located in the southeast of Mexico. It is divided into eight regions: the Isthmus, Mixteca, Sierra Sur, the Coast, Sierra Norte, Central Valleys, Tuxtepec or Papaloapan, and Cañada; furthermore, it is composed of 570 municipalities. The 
population in 2015 was $3,967,889,2,079,211$ women and $1,888,678$ men [3].

In 2013, life expectancy was 72.5 years, which is two years less than the national average; not only is life expectancy lower, a healthy life expectancy is 63.6 years in men and 67.7 years in women, which implies that at least five years of life will be unhealthy [4].

The principal diseases vary by age; the National Survey of Health and Nutrition 2012 (ENSANUT by its initials in Spanish) states that the main causes of childhood morbidity are acute respiratory infections (ARI), followed by diarrheal diseases and urinary tract infections (UTI) [5]. ARIs are presented as the most prevalent in adolescents but the prevalence is modified, as UTIs are listed in second place and diarrheal disease in third. Finally, coupled with these conditions, adulthood hypertension is reported to appear from the age of 20 and diabetes from 40, as shown in Table 1 .

Ten of the previously mentioned diseases are responsible for years of lost healthy life in adults. Diabetes is the number one cause, followed by chronic kidney disease. These conditions highlight the evident economic impact, that despite having acceptable levels of education it has been observed that in different regions work absenteeism caused by illness increases vulnerability [6].

\section{Mortality}

The first three causes of Oaxacan mortality noted in Table 1 are shared with the rest of the country, diabetes being the most significant, followed by ischemic and cerebrovascular diseases with a slightly different variation according to sex.

Amid the main causes of Oaxacan morbidity and mortality are some diseases where the state is at a significant disadvantage compared to others, such as Mexico City or Nuevo León, that have the lowest indexes of social vulnerability. For example, Oaxaca occupies different places in male and female mortality due to malnutrition. Malnutrition is the fifth leading cause of death in women and tenth in men, nevertheless, mortality due to malnutrition is nearly non-existent in Mexico City and Nuevo León [8].

The principal illnesses in the states of Mexico with the highest and lowest social vulnerability reported by the Ministry of Health are displayed in Table 2. According to the level of health, the state of Oaxaca, compared to other states with lower vulnerability indexes, has the highest possible value (32) and, therefore, a lower degree of health.

The table shows the ranking of the principal factors associated with diabetes and hypertension, living conditions and principal causes of mortality [4].

Table 1 Health status of Oaxaca

\begin{tabular}{|c|c|c|c|c|c|c|}
\hline & \multicolumn{3}{|l|}{ Morbidity } & \multicolumn{3}{|l|}{ Mortality } \\
\hline & Women & Men & Total & Women & Men & $\begin{array}{l}\text { Risk Factors commonly } \\
\text { associated to diseases }\end{array}$ \\
\hline 1 & $\begin{array}{l}\text { Acute respiratory } \\
\text { infections }\end{array}$ & $\begin{array}{l}\text { Acute respiratory } \\
\text { infections }\end{array}$ & $\begin{array}{l}\text { Acute respiratory } \\
\text { infections }\end{array}$ & Diabetes & Diabetes & Hyperglycaemia \\
\hline 2 & $\begin{array}{l}\text { Urinary tract } \\
\text { infections }\end{array}$ & $\begin{array}{l}\text { Intestinal infections by } \\
\text { other organisms and } \\
\text { some poorly defined }\end{array}$ & $\begin{array}{l}\text { Intestinal infections by } \\
\text { other organisms and } \\
\text { some poorly defined }\end{array}$ & Ischemic heart & Ischemic heart & Bad dietary habits \\
\hline 3 & $\begin{array}{l}\text { Intestinal infections by } \\
\text { other organisms and } \\
\text { some poorly defined }\end{array}$ & Urinary tract infections & Urinary tract infections & $\begin{array}{l}\text { Cerebrovascular } \\
\text { diseases }\end{array}$ & Cirrhosis & Overweight and obesity \\
\hline 4 & $\begin{array}{l}\text { Gastric ulcers and } \\
\text { duodenitis }\end{array}$ & Conjunctivitis & $\begin{array}{l}\text { Gastric ulcers and } \\
\text { duodenitis }\end{array}$ & $\begin{array}{l}\text { Hypertensive } \\
\text { disease }\end{array}$ & Homicides & $\begin{array}{l}\text { Consumption of alcohol } \\
\text { and drugs }\end{array}$ \\
\hline 5 & Acute vulvovaginitis & $\begin{array}{l}\text { Gastric ulcers and } \\
\text { duodaenitis }\end{array}$ & Conjunctivitis & Malnutrition & $\begin{array}{l}\text { Cerebrovascular } \\
\text { diseases }\end{array}$ & Arterial hypertension \\
\hline 6 & Conjunctivitis & Acute otitis media & Acute otitis media & $\begin{array}{l}\text { Chronic respiratory } \\
\text { diseases }\end{array}$ & $\begin{array}{l}\text { Hypertensive } \\
\text { disease }\end{array}$ & $\begin{array}{l}\text { Low glomerular } \\
\text { filtration }\end{array}$ \\
\hline 7 & Acute otitis media & $\begin{array}{l}\text { Gingivitis and } \\
\text { periodontal diseases }\end{array}$ & $\begin{array}{l}\text { Gingivitis and } \\
\text { periodontal diseases }\end{array}$ & Cirrhosis & Traffic accidents & Malnutrition \\
\hline 8 & $\begin{array}{l}\text { Gingivitis and } \\
\text { periodontal diseases }\end{array}$ & Intestinal amoebiasis & Acute vulvovaginitis & $\begin{array}{l}\text { Acute respiratory } \\
\text { infections }\end{array}$ & $\begin{array}{l}\text { Chronic respiratory } \\
\text { diseases }\end{array}$ & High cholesterol \\
\hline 9 & Intestinal Amoebiasis & Febrile syndrome & Intestinal Amoebiasis & Renal insufficiency & $\begin{array}{l}\text { Acute respiratory } \\
\text { infections }\end{array}$ & Low physical activity \\
\hline 10 & Febrile syndrome & $\begin{array}{l}\text { Pharyngitis, } \\
\text { streptococcal } \\
\text { tonsillitis }\end{array}$ & Febrile syndrome & Congenital & Malnutrition & Smoking \\
\hline
\end{tabular}


Table 2 IIInesses in the states of the Mexican Republic with the highest and lowest social vulnerability

\begin{tabular}{|c|c|c|c|c|c|}
\hline & \multicolumn{5}{|c|}{ Vulnerability } \\
\hline & Oaxaca & Chiapas & Guerrero & $\mathrm{DF}$ & $\begin{array}{l}\text { Nuevo } \\
\text { León }\end{array}$ \\
\hline Mortality rate in children under 5 years & 31 & 30 & 32 & 17 & 2 \\
\hline $\begin{array}{l}\text { Mortality rate due to malnutrition in children } \\
\text { under } 5 \text { years of age }\end{array}$ & 31 & 30 & 29 & 10 & 4 \\
\hline Mortality rate due to cerebrovascular diseases & 31 & 6 & 12 & 27 & 21 \\
\hline Hepatic cirrhosis & 29 & 28 & 12 & 2 & 8 \\
\hline Mortality rate of uterine cervical cancer & 28 & 31 & 26 & 4 & 6 \\
\hline Maternal mortality ratio & 27 & 29 & 30 & 21 & 1 \\
\hline Infant mortality rate & 24 & 22 & 29 & 17 & 2 \\
\hline Moderate malnutrition in children under 5 years & 23 & 17 & 16 & 5 & 31 \\
\hline Mortality rate due to diabetes mellitus & 19 & 23 & 16 & 29 & 10 \\
\hline $\begin{array}{l}\text { Mortality rate due to acute respiratory } \\
\text { infections }\end{array}$ & 18 & 19 & 2 & 31 & 29 \\
\hline Mortality rate in adults over 65 & 15 & 19 & 2 & 4 & 10 \\
\hline Mortality rate in reproductive age & 13 & 11 & 6 & 12 & 9 \\
\hline Mortality rate for prostate cancer & 13 & 26 & 17 & 14 & 10 \\
\hline $\begin{array}{l}\text { Mortality rate from lung cancer, bronchi and } \\
\text { trachea }\end{array}$ & 7 & 8 & 12 & 20 & 28 \\
\hline Mortality rate due to ischemic heart disease & 7 & 3 & 8 & 3 & 27 \\
\hline Harmful consumption of alcohol & 4 & 2 & 10 & 30 & 27 \\
\hline Tobacco use & 2 & 3 & 7 & 29 & 27 \\
\hline Prevalence of diabetes & 1 & 4 & 25 & 32 & 23 \\
\hline Arterial hypertension & 1 & 3 & 15 & 25 & 18 \\
\hline Life expectancy at birth & 0.90625 & 0.9375 & 0.96875 & 0.03125 & 0.125 \\
\hline Life expectancy at 65 & 0.96875 & 1 & 0.9375 & 0.0625 & 0.03125 \\
\hline Prevalence of diabetes & 0.03125 & 0.125 & 0.78125 & 1 & 0.71875 \\
\hline Arterial hypertension & 0.03125 & 0.09375 & 0.46875 & 0.78125 & 0.5625 \\
\hline Harmful consumption of alcohol & 0.125 & 0.0625 & 0.3125 & 0.9375 & 0.84375 \\
\hline Hepatic cirrhosis & 0.90625 & 0.875 & 0.375 & 0.0625 & 0.25 \\
\hline Mortality rate in children under 5 years & 0.96875 & 0.9375 & 1 & 0.53125 & 0.0625 \\
\hline $\begin{array}{l}\text { Mortality rate due to malnutrition in children unde, } \\
5 \text { years of age }\end{array}$ & 0.96875 & 0.9375 & 0.90625 & 0.3125 & 0.125 \\
\hline Maternal mortality ratio & 0.84375 & 0.90625 & 0.9375 & 0.65625 & 0.03125 \\
\hline Mortality rate in reproductively active age & 0.40625 & 0.34375 & 0.1875 & 0.375 & 0.28125 \\
\hline Mortality rate in adults over 65 & 0.46875 & 0.59375 & 0.0625 & 0.125 & 0.3125 \\
\hline Mortality rate due to acute respiratory infections & 0.5625 & 0.59375 & 0.0625 & 0.96875 & 0.90625 \\
\hline Mortality rate of uterine cervical cancer & 0.875 & 0.96875 & 0.8125 & 0.125 & 0.1875 \\
\hline Mortality rate for prostate cancer & 0.40625 & 0.8125 & 0.53125 & 0.4375 & 0.3125 \\
\hline $\begin{array}{l}\text { Mortality rate from lung cancer, bronchi and } \\
\text { trachea }\end{array}$ & 0.21875 & 0.25 & 0.375 & 0.625 & 0.875 \\
\hline Mortality rate due to cerebrovascular diseases & 0.96875 & 0.1875 & 0.375 & 0.84375 & 0.65625 \\
\hline Mortality rate due to ischemic heart disease & 0.21875 & 0.09375 & 0.25 & 0.09375 & 0.84375 \\
\hline \multicolumn{6}{|l|}{ Living conditions } \\
\hline Households with appropriate water sources & 0.96875 & 0.9375 & 1 & 0.0625 & 0.03125 \\
\hline Housing with sanitary service & 1 & 0.875 & 0.9375 & 0.03125 & 0.0625 \\
\hline Houses with indoor air pollution & 1 & 0.96875 & 0.9375 & 0.03125 & 0.09375 \\
\hline Physical inactivity & 0.0625 & 0.15625 & 0.09375 & 0.125 & 0.3125 \\
\hline Sedentary lifestyle & 0.03125 & 0.0625 & 0.0625 & 0.96875 & 0.5 \\
\hline Overweight and obesity in adults & 0.0625 & 0.125 & 0.15625 & 0.78125 & 0.84375 \\
\hline Total & 13 & 12.84375 & 12.53125 & 9.96875 & 8.96875 \\
\hline
\end{tabular}

Data from the Informe de Salud de los Mexicanos 2015 [4] The table shows the ranking of the principal illnesses in the states with the most and least index of vulnerability. The highest value represents the worst conditions. 
Among the risk factors associated with mortality in the state are: hyperglycaemia, poor dietary habits, overweight and obesity, alcohol and drug consumption, hypertension, low glomerular filtration rate, malnutrition, high cholesterol, low physical activity and smoking [4].

\section{Social factors health related}

Although mortality associated factors are biological, it is worth considering other factors that are present in the everyday environment, particularly poverty. $65.9 \%$ of the population is impoverished, far above the national rate of $49.5 \%$, and indicators such as education, housing and access to health services are far below national averages [4].

A high percentage of Oaxacans speak an indigenous language (34\%). The state's unique characteristic is that most of the population is distributed around the 245 municipalities where 26 indigenous languages are spoken, and one- fifth of the inhabitants do not speak Spanish. The predominant languages are Zapotec, Mixtec, Mazatec and Chinantec [9].

\section{Education}

Despite having great cultural diversity, the educational level is very low. $6 \%$ of the population is illiterate, more than twice the national level (13\%); the average educational level of persons older than 15 is 7.5 years of formal schooling, lower than the national level of 9.2; $11 \%$ have never attended school, and finally, $51.8 \%$ of the population has a low educational level [3].

\section{Housing}

It is important to highlight that $65.9 \%$ of the population live in conditions of poverty, a situation that reflects the lack of basic services; it is also important to note that more than $20 \%$ of the population are without access to appropriate water sources, $31.2 \%$ are without access to sanitary services (disposal of excreta), $11 \%$ of the houses have dirt floors-an index markedly above the 3.2\% national average- only $43.2 \%$ of the houses are built with a roof of resistant material and $11.6 \%$ of homes do not have water, electricity or gas, therefore occupying the penultimate place in the nation $[4,10]$. Furthermore, these conditions of poverty have a direct impact on health conditions, particularly water and indoor air pollution $[11,12]$.

According to the World Health Organization (WHO) there are several diseases related to water caused by faecal-oral transmission of microorganisms and chemical substances present in drinking water [7]. Diseases such as ascariasis, onchocerciasis, typhoid, schistosomiasis, campylobacter infection, cholera, diarrhoea and paratyphoid enteric fevers; these diseases are related to faecal-oral transmission by non-potable water. Parasitic diseases arise from a contaminated water source, which produces conditions such as diarrhoea that in conjunction with collateral risk factors generate various problems. The probability of parasitic illness is increased by consuming water from unsuitable groundwater tables or by drinking water that includes an intermediate mollusc, causing water-borne diseases such as schistosomiasis $[7,11,13-16]$.

However there are other diseases that have to do with the lack of access to water, such as malaria, where the transmission and reproduction of the Aedes aegypti mosquito is related to water storage. Once the water has been collected, it must be stored, which increases the possibility of disease-bearing vectors, such as malaria, Zika virus and Chinkungunya, transmitted by Aedes aegypti [15-18] Villagers have a long walk to get clean water, and as a result, the same sanitary issues that concerned people in the early nineteenth century are still current in Oaxaca.

A fundamental feature of theses living conditions is that $49.5 \%$ of homes are saturated with polluted air, ranked as the last place in the country [4]. This polluted air is generated by the use of solid fuels such as wood, agricultural waste, charcoal, coal and animal excrement for cooking and heating inside the home. [12]

These fuels produce large amounts of particles such as soot, which penetrates deep into the lungs $[19,20]$ moreover, if in addition homes are poorly ventilated with dirt floors, there is an increase of air pollutant particles, resulting in even more unfavourable living conditions.

Health issues arise from such exposure, and women and children are the most affected. It is well-known that being exposed to indoor air pollution almost doubles the risk of pneumonia during childhood and that more than half the deaths in children less than five years of age are caused by acute lower respiratory infection due to inhalation of indoor air contaminated by solid fuel [12].

It is well known that particle-polluted air produces respiratory diseases, such as cancer, asthma and emphysema, and drastically increases the probability of suffering acute respiratory infections. In fact, WHO has estimated that one out of every three respiratory infections worldwid, is associated with exposure to polluted air [12]. The results of inhaling particles generated by combustion, depending on the specific particle, are irritation, inflammation and hyper-reactivity; these particles reduce mucociliary and thus, macrophage response, they are also haemoglobin bound and thus reduce oxygen transport; the more bronchial reactivity, the more susceptibility to infections, even carcinogenic ones [21]. The damage caused by this pollution is considered to be as alarming as tobacco smoke [22].

While the respiratory effects of contaminated air inhalation is well known, WHO reports that of the 4.3 million people in the world who die prematurely due to inhaling polluted air, $12 \%$ is due to respiratory diseases, specifically 
pneumonia, while the rest are due to other conditions that are probably not related to that exposure; $34 \%$ cerebrovascular accidents, $26 \%$ ischemic heart disease, $22 \%$ chronic obstructive neuropathy, and $6 \%$ due to lung cancer. Contaminated air inhalation has even been associated with diabetes and preeclampsia [23]. It is important to highlight that such conditions include three of the main causes of morbidity and mortality in Oaxaca.

Once pollutants enter the body through the respiratory tract producing chronic inflammation, pro-inflammatory cytokines are secreted, which triggers chronic inflammation and immunological responses. Once settled in the bloodstream these particles cause cardiovascular damage in various ways, such as the induction of oxidative stress, systemic inflammation, endothelial dysfunction, thrombosis that generates heart failure or ischemic diseases and arrhythmias. Additionally, accumulation of these contaminants in the arteries may form obstructions similar to those caused by high-fat diets [24].

A large number of diseases prevalent in Oaxaca are associated with living conditions as shown in Table 3, such as limited access to suitable water sources, lack of access to sanitary services, a proper place for excreta disposal or exposure to polluted air.

Summary of the 20 leading causes of disease in the state of Oaxaca that, according to $\mathrm{WHO}$, are related to the lack of appropriate water sources, lack of access to sanitary services and the use of solid fuel in the home.

\section{Discussion}

Urinary tract infections are associated with kidney failure and ischemic heart disease and cerebrovascular accidents are associated with high cholesterol, high triglycerides or obesity (64.6\% of the population) and arterial hypertension. Ischemic heart disease, in the case of Oaxaca, cannot be attributed solely to the presence of high levels of serum carbohydrates, in view of the high level of physical activity of the population. With $90 \%$ of the population active, Oaxaca is positioned as the state with less physical inactivity, shown by the few hours that people spend in front of the television. This is probably a function of poverty, as people have to walk everywhere, cannot afford television, and live in areas without access to television or Internet signals.

Hence, it is necessary to consider that breathing contaminated air inside the home is a social factor that may be associated with the three main causes of mortality in Oaxaca, especially in women, since they are the most exposed to polluted air due to cooking and time spent within the home. When biological factors are not enough to explain causality, the answer is surely related to social factors.

To reduce morbidity and mortality in Oaxaca, in addition to complying with the vaccination programs and recommendations issued by $\mathrm{WHO}$, it is necessary to analyse the possibility of environmental interventions that are closely related to health.

In 2015 the United Nations proposed that with the implementation of 17 global goals, life could be improved for people around the world. To achieve these objectives the united efforts of government, business and civil society is necessary. The goal of Sustainable Development Goals 3 (SDG3) is to ensure healthy lives and promote well-being for all. Additionally, there are health related SDGs, such as SDG6, that focus on ensuring availability and sustainable management of water and sanitation for all, and SDG 7, dedicated to ensure access to affordable, reliable, sustainable and modern energy for all [25]. SDG6 is directly related to SDG3, as providing good quality water reduces tropical diseases like malaria and water-borne diseases. The SDG reports mention that in Mexico, mortality attributed to household air pollution is $15.2 \%$, but in Oaxaca it is much greater, at $23.5 \%$, and unsafe water, unsafe sanitation and lack of hygiene is 1.1 per 100,000 population [25]. Although worldwide access to water sources and waste disposal has improved, the situation of different regions or states of a country may be far from the national averages [26] and local problems may be underestimated.

The lack of access to appropriate sources of water and the use of fuels other than gas or electricity are not problems that poor people can solve on their own in order to prevent the deterioration of their health. In some cases the solution may be unknown, their living situation places them at a disadvantage and they lack the resources to modify their environment.

The reduction of use of solid fuel for heating and cooking, and improved sanitation, is not a key objective in some countries because it is not directly related to non-communicable diseases. As Krieger points out, the disadvantages in social epidemiology are not mutually

Table 3 Diseases prevalent in Oaxaca associated with vulnerability factors

\begin{tabular}{|c|c|c|c|}
\hline Vulnerability factors & Place among the health risk* & Percentage & Associated diseases according to $\mathrm{WHO}$ \\
\hline Access to suitable sources of water & Penultimate (31) & $80 \%$ & \multirow{2}{*}{$\begin{array}{l}\text { Ascariasis (helminthiasis), malaria, onchocerciasis, } \\
\text { schistosomiasis, campylobacteriosis, diarrhoea typhoid, } \\
\text { paratyphoid enteric fevers, anaemia, malnutrition. }\end{array}$} \\
\hline Houses with access to sanitary services & Last (32) & $66 \%$ & \\
\hline Indoor polluted air exposure & Last (32) & $49.3 \%$ & \multirow{2}{*}{$\begin{array}{l}\text { Pneumonia, chronic obstructive pneumonia stroke, } \\
\text { ischemic heart disease. }\end{array}$} \\
\hline Indoor usage of solid fuel & Last (32) & $49.3 \%$ & \\
\hline
\end{tabular}

Source: data from Informe de la Salud de los Mexicanos 2015 [4] 
exclusive, [27] and in this case they are associated with the prevailing conditions in Oaxaca. Oaxaca displays a biological expression of social inequality, since people are incorporating pollutant particles into their bodies by inhaling them during their daily activities and thus, the population expresses biologically the experiences of economic inequality due to the impoverished conditions in which they live, leading to an untimely death [27]. The difference in health conditions with the rest of the country is not a matter of race or ethnicity, but of the living conditions of these ethnic groups. Women and children being the most affected, biological affectation has a lifelong trajectory development, which could be considered as "biological programming" in which the harm that has occurred during childhood has repercussions throughout the rest of life.

Although there has been an increase in health expenditures in the state of Oaxaca, it is quite obvious that there is still a lot more to be done. Despite the fact that a large part of the population has government health insurance (Seguro Popular) 15.9\% do not have access to health services, and $83.8 \%$ do not have access to social security $[4,10]$. Moreover, within the population that has access to health services, ENSANUT reports that in 2012 the rate of these services was $66.8 \%$, lower than the $77 \%$ national rate [5] . Nevertheless, being affiliated with the health system does not necessarily indicate that access to the services is full and effective. Additionally, user reports on quality and effective access to health services in Oaxaca indicated that the people who were attended either did not receive their full medication prescriptions or had to pay for laboratory studies or medications during surgical treatment [28]. The actions of the SDGs related to health can reduce the main causes of morbidity and mortality in Oaxaca and places Mexico as one of the countries that improves the life of the population through the application and fulfilment of the SDG goals.

\section{Conclusions}

As can be deduced, opening more clinics is not the solution, as there will probably be no doctors, not enough medicines and the location will be inaccessible to the population. If Oaxacans have the same rights to health services as the rest of the country, then the causes of social disadvantage are the immediate problem and the causes of morbidity and mortality which do not present risk factors such as lack of physical activity and/or diabetes, will require multifaceted action for health improvement, specifically in the construction of healthy environmental conditions.

Therefore, if actions were to be implemented to reduce the two factors of contaminated air and water that have been established as global objectives, as in the millennium development goals of SDGs 3, 6 and 7, Oaxaca's morbidity and mortality would be reduced. WHO has suggested a plan called Water, Sanitation and Hygiene, with the objective of accelerating and sustaining progress in respect to unattended tropical diseases (WASH) and thus to control and eliminate them [29]. An excellent example is improving health by clearing the air to reduce premature mortality from non-communicable diseases. Policies implemented to reduce the exposure to dangerous particles have reduced cardiovascular mortality from $17.8 \%$ in 2000 to $10.3 \%$ in 2015 [30].

Additionally it has been observed that changing fuel material, ventilating homes or increasing the quantity of multivitamin tablets, increases the function of the immune system and thus reduces respiratory infections. These measures have been taken by other countries to reduce the production of pollutants within the home $[31,32]$. And, as with any measure, it must go hand in hand with national health programs.

\section{Abbreviations}

ARI: Acute respiratory infection; ENSANUT: National survey of health and nutrition; INEGI: National Institute of Statistics and Geography; SESA: Ministry of health; UTI: Urinary tract infection; WHO: World Health Organization

\section{Acknowledgements}

We thank the Universidad de la Sierra Sur (UNSIS) for supporting this work.

\section{Funding}

This work was supported by PRODEP UNSIS-PTC-093.

\section{Availability of data and materials}

The data supporting the results reported in this manuscript are included in published articles cited in the text. The documents are available in: https:// www.dropbox.com/sh/x5a8if6huo0vyl2/AABRLttp2hUstqD43wcytAYQa?dl=0

\section{Authors' contributions}

AMGV and RAAZ have equal contribution in the conception, acquisition of data and drafting the manuscript. Both authors read and approved the final manuscript.

Ethics approval and consent to participate

Not applicable.

Consent for publication

Not applicable.

Competing interests

The authors declare that they have no competing interests.

\section{Publisher's Note}

Springer Nature remains neutral with regard to jurisdictional claims in published maps and institutional affiliations.

Received: 11 May 2018 Accepted: 21 August 2018

Published online: 03 September 2018

\section{References}

1. McCarthy JJ. Climate change 2001: impacts, adaptation, and vulnerability: contribution of working group II to the third assessment report of the intergovernmental panel on climate change: Cambridge University Press. Vol 2. 2001

2. Aday LA. At risk in America: the health and health care needs of vulnerable populations in the United States. Vol 13. Wiley; 2002.

3. Instituto Nacional de Estadistica y Geografía. Principales resultados de la Encuesta Intercensal 2015. Oaxaca: INEGl; 2015. p. 107. 
4. Secretaria de Salud. Informe sobre la Salud de los Mexicanos 2015. México: Diagnóstico General de la Salud Poblacional. (Subecretaria de Integracion y Desarrollo del Sector Salud. Direccion General De Evaluacion al Desempeño ed; 2015. p. 200

5. Instituto Nacional de Salud Pública. Encuesta Nacional de Salud y Nutrición 2012. In: Resultados por entidad federativa Oaxaca. Cuernavaca: INSP INdSP; 2013. p. 112

6. González RV. Vulnerabilidad social y su distribución espacial: el caso de las entidades federativas de México, 1990-2010. Paradigma económico. 2011;3: 85-111.

7. Organizacion Mundial de la Salud. Agua, Saneamiento y Salud. La carga de la enfermedad y los estimados costo eficacia. 2018. http://www.who.int/ water_sanitation_health/diseases/burden/es/.

8. Knickman J, Bethell C, Fiorillo J, Lansky D: A portrait of the chronically ill in America, 2001. 2002.

9. Comisión Nacional Para el Desarrollo de los Pueblos Indígenas. Condiciones Socioeconómicas y Demográficas de la Población Indígena. CDI:PNUD ed. vol. Tomo 1. , Primera edition. Mexico: CDl; 2008. p. 201.

10. Consejo Nacional de Evaluación de la Política de Desarrollo Social. Pobreza estatal 2016. Oaxaca; CONEVAL: 2018.

11. Strunz EC, Addiss DG, Stocks ME, Ogden S, Utzinger J, Freeman MC. Water, sanitation, hygiene, and soil-transmitted helminth infection: a systematic review and meta-analysis. PLoS Med. 2014;11:e1001620.

12. Bruce N, Pope D, Rehfuess E, Balakrishnan K, Adair-Rohani H, Dora C. WHO indoor air quality guidelines on household fuel combustion: strategy implications of new evidence on interventions and exposure-risk functions. Atmos Environ. 2015;106:451-7.

13. Pérez GT, Rodríguez DEA. Comportamiento humano y prevención de dengue: Estudio en barrios endémicos de Barranquilla, Bucaramanga y Armenia (Colombia). Campos en Ciencias Sociales. 2015;3:199-214.

14. Bauman Z. Collateral damage: social inequalities in a global age: Polity Press; 2011. p. 2-9.

15. Sclar GD, Penakalapati G, Amato HK, Garn JV, Alexander K, Freeman MC, Boisson S, Medlicott KO, Clasen T. Assessing the impact of sanitation on indicators of fecal exposure along principal transmission pathways: a systematic review. Int J Hyg Environ Health. 2016;219:709-23.

16. Organización Mundial de la Salud: Agua, saneamiento e higiene. Enfermedades relacionadas con el agua. 2018

17. Prüss-Üstün AK, Fewtrell D, Bartram L, Jamie. Unsafe water, sanitation and hygiene. In: Comparative Quantification of Health Risks: Global and Regional Burden of Disease due to Selected Major Risk Factors; 2004. p. 2.

18. Padmanabha $H$, Soto E, Mosquera M, Lord C, Lounibos L. Ecological links between water storage behaviors and Aedes aegypti production: implications for dengue vector control in variable climates. Ecohealth. 2010; 7:78-90.

19. Kennedy IM. The health effects of combustion-generated aerosols. Proc Combust Inst. 2007;31:2757-70.

20. Bruce N, Perez-Padilla R, Albalak R. Indoor air pollution in developing countries: a major environmental and public health challenge. Bull World Health Organ. 2000;78:1078-92.

21. Perez-Padilla R, Schilmann A, Riojas-Rodriguez H. Respiratory health effects of indoor air pollution. Int J Tuberc Lung Dis. 2010;14:1079-86.

22. World Health Organization. Indoor air pollution from solid fuels and risk of low birth weight and stillbirth: report from a symposium held at the September 2005. Johannesburg: Annual Conference of the International Society for Environmental Epidemiology (ISEE); 2007.

23. Agrawal S, Yamamoto S. Effect of indoor air pollution from biomass and solid fuel combustion on symptoms of preeclampsia/eclampsia in Indian women. Indoor Air. 2015:25:341-52.

24. Mills NL, Donaldson K, Hadoke PW, Boon NA, MacNee W, Cassee FR, Sandström T, Blomberg A, Newby DE. Adverse cardiovascular effects of air pollution. Nat Clin Pract Cardiovasc Med. 2009;6:36-44.

25. Statistics WH. Monitring health for the SDGs Sustainable development goals. Geneva: World Health Orga ization; 2017.

26. Social CE. Progresos realizados para lograr los Objetivos de Desarrollo Sostenible; 2018. p. 1-21.

27. Krieger N. Glosario de epidemiología social. Rev Panam Salud Publica. 2002; 11:480-90

28. Accion Ciudadana Frente a la Pobreza. Reporte ciudadano sobre Calidad y Acceso Efectivo a la Salud. Oaxaca: Accion ciudadana; 2015. p. 52.
29. Organizacion Mundial de la Salud. Agua, Saneamiento e higiene para acelerar y sostener el progreso respecto a las enfermedades tropicales desatendidas. Una estrategia mundial 2015-2020. Ginebra: OMS; 2015. p. 36.

30. WHS 2017. Monitoring health fot the SDGs sustainable development goals. World Health Organization; 2017. p. 1-116.

31. Flannigan B, Samson RA, Miller JD. Microorganisms in home and indoor work environments: diversity, health impacts, investigation and control. CRC Press; 2016.

32. Haryanto B, Suksmasari T, Wintergerst E, Maggini S. Multivitamin supplementation supports immune function and ameliorates conditions triggered by reduced air quality. Vitam Miner. 2015:4:2376-1318.1000128.

\section{Ready to submit your research? Choose BMC and benefit from:}

- fast, convenient online submission

- thorough peer review by experienced researchers in your field

- rapid publication on acceptance

- support for research data, including large and complex data types

- gold Open Access which fosters wider collaboration and increased citations

- maximum visibility for your research: over $100 \mathrm{M}$ website views per year

At BMC, research is always in progress.

Learn more biomedcentral.com/submissions 